\title{
Motivation in a Foreign Language Teaching and Learning
}

\author{
Lalu Thohir \\ English Education Program UniversitasMataram \\ mq.afif@gmail.com
}

\begin{abstract}
In learning English as a foreign language, where learners are separated logistically and psychologically from the target culture, motivation plays a critical role, and it is one of the main determining factors in a second/foreign language learning achievement. Motivation is defined as some internal drive which pushes someone to do things in order to achieve something and to achieve success; someone needs to be motivated. Motivation is distinguished into different kinds, such as integrative and instrumental, intrinsic and extrinsic, global, situational and task. However, the most widely cited distinction of motivation is between intrinsic and extrinsic motivation. In the field of language learning, motivation is sometimes distinguished from orientation. As an ideal for self-determined behavior, the intrinsic motivation is considered to be more powerful than extrinsic motivation in the success of learning a language. However, most of the learning activities which the language learners do are initiated and driven by extrinsic motivation. There are three areas - goalsand goal setting, learning environment, and exciting classes - in which the language teachers could directly influence the language learners' motivation and their continuing participation in the classroom. Providing positive feedback and enhancing the autonomous learning are among important means to increase the learners' motivation. Also, emphasizing two forms of positive extrinsic motivation identification, and integration, while minimizing two forms of negative extrinsic motivation - external regulation and introjection could boost the intrinsic motivation of the learners.
\end{abstract}

ARTICLE HISTORY

Received 16 April 2017

Accepted20 August 2017

\section{KEYWORDS}

language learning and acquisition; second and foreign language; motivation; intrinsic and extrinsic motivations; positive and negative extrinsic motivations; positive feedback; autonomous learning.

\section{Introduction}

There's no doubt that motivation is crucial to success for most fields of learning, in that we need to have a desire to do something to succeed it. Without such motivation, we will almost certainly do not engage in some activities or do not make the necessary effort to complete an action or to achieve a specific goal.

When we speak about English language learning success or failure, we often associate it with the motivations of language learners. Due to the vital role of motivation in learning English as a foreign language (EFL), it is necessary for the EFL teachers to take care of their students' motivation and to arouse their interest in learning and to maintain this state of arousal. This paper is an attempt to look at a theoretical approach to motivation including what motivation means, kinds of 
motivation and what can drive language learners motivated for learning. Besides, to have a better point of view concerning learning English in the context of the educational program in Indonesian, it is worth noting the distinction between language learning and language acquisition and between foreign language and second language.

\section{Language Learning and Language Acquisition}

Language knowledge stems from two sources: what is learned and what is acquired. Learning is the conscious process of studying and intellectually understanding the grammar of the second language. The acquisition, on the other hand, refers to the unconscious absorption of general principles of grammar through real experiences of communication using the second language. It is the basis for most first language ability and regarding the second language is commonly known as 'picking up a language' (Terral, 1977).

Some theorists use 'learning' and 'acquisition' synonymously. Others maintain a contrast between the two terms, using 'learning' to mean a conscious process involving the study of explicit rules of language, as is often typical of classroom learning in a foreign language and using 'acquisition' to refer to a nonconscious process of rule internalization resulting from exposure to comprehensible input when the learner's attention is on meaning rather than form, as is more common in a second language context. Still, others use 'acquisition' only concerning the learning of one's first language (Richards \&Schmidt, 2002).

Krashen (2009:10) views the distinction between acquisition and learning from the ways of people develop competence in a second language. The first way islanguage acquisition, a process similar, if not identical, to the way children develop ability in their first language. Language acquisition is a mental process; language acquirers are not usually aware of the fact that they are using the language for communication. Other ways of describing acquisition include implicit learning, informal learning, and natural learning. In non-technical language, the acquisition is "picking up" a language. The second way to develop competencein a second language is by language learning. Krashen uses the term "learning" to refer to conscious knowledge of a second language, knowing rules, being aware of them, and being able to talk about them. In non-technical terms, learning is "knowing about" a language, known to most people as "grammar" or "rules." Some synonymous include the formal language of a language or explicit learning. In short, as it is stated in Encyclopedia of Bilingual Education (2008:470), Krashen uses the term learning to refer to a conscious process of language development that occurs as a result of direct teaching. In contrast, the acquisition is a subconscious process of language development that occurs as the result of exposure to meaningful messages in a language. 


\section{Second and Foreign Language Learning}

Learning a language is often associated with whether a language learned is a second or a foreign language for the language learners. Ellis (1999:12) provides as with prominent description about a distinction between second and foreign learning. He explains that a distinction lies in the setting where it takes place. The second language is a language that plays an institutional and social role in the community, i.e., it functions as a recognized means of communication among members who speak some other language as their mother tongue. For example, English as a second language is learned in the United Kingdom and countries in Afrika such as Nigeria and Zambie. In contrast, foreign language learning takes place in settings where the language plays no significant role in the community and is primarily learned only in the classroom. For example, English as a foreign language is learned in Indonesia or Japan.

English is regarded as a foreign language in the countries where English is mostly treated as an academic subject in the school's system and is not widely used outside the classroom. In contrast, English is regarded as a second language in countries where English is widely used and is perceived as essential to success (Peace Corps, 1989). Regarding the ideas above, we can conclude that English is still regarded as a foreign language in Indonesia.

\section{Motivation in alanguage Learning}

\section{Definition and Kinds of Motivation}

Motivation, as a critical factor in the process of learning and teaching, is defined as some internal drive which pushes someone to do things in order to achieve something(Harmer, 2001:51). Williams and Burden (1997) as cited in Harmer (2001:51) view motivation as a state of cognitive arousal which provokes a decision to act as a result of which there is sustained intellectual and physical effort so that the person can achieve some previously set goal. In a similar view, Brown (2000:72) defines motivation as the extent to which someone makes choices about goals to pursue and the effort he/she will devote to that pursuit.

Some distinction has been made concerning motivation as an internal drive or cognitive arousal which provokes someone to do things in order to achieve something. Ur (2009:276) presents three distinctions concerning different kinds of motivation: a distinction between integrative and instrumental motivation (the desire to identify with and integrate into the target-language culture and the wish to learn the language for purposes of study or career promotion), between intrinsic and extrinsic motivation (the urge to engage in the learning activity for its own sake and 
motivation that is derived from external incentives), and a distinction between global, situational and task motivation (the first is overall orientation of the learner towards the learning of the foreign language; the second has to do with the context of learning (classroom, total environment); and the third with the way the learner approaches the specific task in hand).

In the field of language learning, a distinction is sometimes made between orientation and motivation.Brown (2000:75) states that orientation means a context or purpose for learning and motivation refers to the intensity of one's impetus to learn. Orientation is usually used and associated with the second language learning. The orientation for second language learning might be integrative and instrumental. The former refers to a desire to learn a language stemming from a positive effect toward a community of its speaker in which the learner is pursuing a second language for social and cultural purposes. While, the latter refers to a desire to learn a language in order to attain a particular career, educational or financial goals. Further, it is claimed that an integrative orientation was more strongly linked to success in learning a second language than an instrumental orientation.

\section{Intrinsic and Extrinsic Motivation in Language Learning}

A widely cited distinction of motivation in learning a language is intrinsic motivation and extrinsic motivation, whether it comes from inside and outside. Harmer (2001:51) points out that intrinsic motivation is that which comes from within the individual in which a person might be motivated by the enjoyment of the learning process itself or by a desire to make themselves feel better. The extrinsic motivation, on the other hand, is that which comes from outside factors, for example, the need to pass an exam, the hope of financial reward, or the possibility of future travel. In a broad sense, Lai (2011) states that intrinsic motivation is animated by personal enjoyment, interest or pleasure, whereas reinforcement contingencies govern extrinsic motivation. Thus, the intrinsic motivation in English language learning is about the enjoyment of language learning itself, whereas extrinsic motivation is driven by external factors such as academic requirements or rewards and punishments. As a result, with intrinsic motivation, a language learner is encouraged to do a task or engage in a classroom activity purely because of enjoyment or fun, whereas with extrinsic motivation, in contrast, a language learner is encouraged to do a task or engage in a classroom activity mainly because doing so will yield some kind of reward or benefit upon completion,

In an educational program, it is claimed that intrinsic motivation is more powerful than extrinsic motivation. Intrinsic motivation is considered to result in better learning outcomes than extrinsic motivation. However, in an EFL program, most of the language learners engaging in learning activities are driven by external motivations. Harmer (2001:51) points out that even where the original reason for taking up a language course, for example, is extrinsic, the chances of success will be 
significantly enhanced if the students come to love the learning process. A study conducted by Vansteenkiste, Lens, and Deci (2006) demonstrated that natural goal framing (compared to extrinsic goal framing and no-goal framing) produced deeper engagement in learning activities, better conceptual learning, and higher persistence at learning activities.

In his article in the anthology of current practice in methodology in language teaching, Brown (2002:13) states that sometimes, reward-driven behavior is dependent on extrinsic motivation. However, a more powerful category of reward is one which is intrinsically driven within the learner. He adds that when behavior stems from needs, wants, or desires within oneself, the behavior itself has the potential to be self-rewarding. In such a context, externally administered rewards are unnecessary; learners are likely to maintain the behavior beyond the immediate presence of teachers, parents and other tutors. In a similar view, Maslow (1970) as cited in Brown (2000:76) states that once the learners are internally motivated, no matter what extrinsic rewards are present or absent, they will strive for self-esteem and fulfillment.

\section{Sustaining Motivation inLanguage Teaching}

Due to the vital role of motivation in achieving the success of language learning, it is one of the teacher' responsibilities to keep his/her students interested and motivated in learning. For this end, the language teacher needs to know the factors affecting the motivations of their students in learning and to understand areas where they can directly influence the students' continuing participation in the classroom activities.

Harmer (2001:52) points out that there are four factors which can influence the students' motivation to do the task of learning English as they form part of the world around students' feeling and engagement with the learning process. First, the society where the students live in. The extent to which the social attitudes to language learning and the English language, in particular, will determine and influence the students' attitude to the language being studied which in its turn have a profound effect on the degree of motivation the student brings to class. Second, the people who are close to them such as parents, older siblings, and peers. The students' attitude to language learning will be greatly affected by the influence of those people. Third, the teacher who is considered as a major factor in the continuance of a student's motivation. The teacher's attitude towards the language and the task of learning will be vital to the students' motivation for learning English. Fourth, the method which is vital to create confidence for both teacher and students in the way teaching and learning take place. Once both teacher and students are comfortable with the method being used, success is much more likely.

As students who come to the class to learn have a range of motivation, some of them may come with strong motivation, and some others may come with weak 
motivation, it is the teacher's responsibility to direct and increase students' motivation in order to keep their continuing participation in classroom activities. According to Harmer (2001:53), there are three areas in which teachers can directly influence the students' motivation. The first is goals of learning: students' goal in learning consists of long-term, such as the passing of an exam and the probability of a better job in the future, and short-term goals, such as the successful writing of an essay, the passing of the progress test at the end of the week. As the long-term goals often seem too far away, it is much easier to focus on the end of the week than the end of the year. If the teacher can help students in the achievement of short-term goals, this will have a significant effect on their motivation. The second is a learning environment. It involves the classroom physical appearance and the emotional atmosphere of the lesson. The teacher can decorate even the most unattractive classroom with all kinds of visual material, and the teacher also can still change the atmosphere through such things as the use of music. When students walk into an attractive classroom at the beginning of a course, it may help to get their motivation for the process going. However, creating and sustaining the emotional atmosphere is more important than decorating the classroom.The third is an exciting class. To continue to be intrinsically motivated, the students need to be interested both in the subject they are studying and in the activities and topics they are presented with. The teacher needs to provide the students with a variety of subjects and exercises to keep them engaged. The choice of the material to take into the class will be crucial too, but more important than this will be how it is used in the lesson.

There are some other essential means which a language teacher needs to do to promote the right classroom emotional atmosphere and to arouse the motivation of students for learning. Giving positive feedback and providing autonomous learning can be an essential means of sustaining students' participation in classroom activities. Brown (2000:77) states that the positive feedback that learners perceive can be a boost to their feelings of competence and self-determination which in its turn can increase or maintain their intrinsic motivation. Providing positive feedback according to Richards (2007:188) may serve not only to increase motivation but also to build a supportive classroom climate and to let learners know how well they have performed. In order that feedback is positive, Westwood (2009:70) urges that the feedback should come in the form of descriptive praise (i.e., well done, good job, and others.) if the student's work is good. On the other hand, if a student's work is incorrect, the teacher should provide immediate correction to help remove the misconception and to supply accurate information. However, the most important thing in giving feedback is that it should be delivered in a positive emotional tone, not with annoyance or frustration.

Regarding learner autonomy, Brown (2000:77) states that if the learners are given an opportunity to do language for their reasons of achieving competence and autonomy, they will have a better chance of success than if they become dependent 
on external rewards for their motivation. There are various techniques or activities which language teachers can adapt to enhance learner autonomy at the same time to promote learner-centered learning. Farrel \& Jacobs (2010:19-20) represent several means of enhancing learner autonomy such as promoting collaborative learning (i.e. through the use of small group and pairs), encouraging a life-long reading habit (i.e. through the use of extensive reading or student-selected reading) and self-assessment as the sole judge of the language learners' strengths and weaknesses. The idea for self-assessment is for language learners to develop their internal criteria for the quality of their work, rather than being independent on external evaluation or evaluators.

As different forms of extrinsic motivation can have positive or negative effects on intrinsic motivation, Sell (2008:263) encourages that, wherever and whenever possible, teachers to emphasize two forms of positive extrinsic motivation identification (the process by which students begin to internalize the value of their behaviors and to accept them as their own) and integration (the process by which students identify with the behaviors performed, fully endorse them, and integrate those behaviors with other aspects of the self). In contrast, Sell urges teachers to use sparingly, if at all, two forms of negative extrinsic motivation - external regulation (the process by which student behavior is controlled by specific external contingencies such as rewards and punishments) and introjection (the process by which student behavior is controlled by creating guilt or shame)

\section{Conclusion}

Motivation, in general, is defined as the driving force in any situation that leads to action. In the field of language learning, a distinction is sometimes made between an orientation (a class of reasons for learning a language) and motivation (a combination of the learner's attitude, desires and willingness to expend effort in order to learn the second or foreign language). There are many kinds of motivation, and the most widely cited distinction of motivation is between intrinsic motivation (about the enjoyment of language learning itself) and extrinsic motivation (driven by external factors such as academic requirements or other sources of rewards and punishments). As an ideal for self-determined behavior, it is claimed that intrinsic motivation is more powerful than extrinsic motivation for the success of learning.

Considering the critical role of motivation in the success of learning a second or foreign language, it is critically important that a language teacher make attempts to keep the learners motivated for learning. There are three areas - goalsand goal setting, learning environment, and exciting classes - in which the language teachers can directly influence the students' motivation. Providing positive feedback and enhancing autonomous learning are also crucial to arouse and maintain the learners' motivation. The language teachers need to be careful when giving feedback to their 
students, in which they need to give constructive feedback and deliver itin a positive emotional tone. Moreover, to enhance learner autonomy, the language teachers can organize collaborative learning,promote a life-long reading habit and encourage selfassessment.

Also, to promote the learners' intrinsic motivation, it is encouraged that, whenever and wherever possible, language teachers to emphasize two forms of positive extrinsic motivation - identification and integration and to use sparingly if at all, two forms of negative extrinsic motivation - external regulation and introjection. 


\section{References}

Brown, H. Dougles. (2000). Teaching by Principles. An Interactive Approach to Language Pedagogy. Second Edition. New York: Pearson Education

Brown, H. Dougles. English Language Teaching in the "Post-Method" Era: Toward Better Diagnosis, Treatment, and Assessment. In Richards, Jack C. \& Renandya, Willy A. (ed. 2002) Methodology in Language Teaching. An Anthology of Current Practice. USA: Cambridge University Press

Dunlap, Carmen Zuniga \& Weisman, Evelyn Marino. (2007). Helping English Language Learners Succeed. USA: Shell Education.

Ellis, Rod. (1999). The Study of Second Langauge Acquisition. Oxford: Oxford University Press

Farrell, Thomas S.C. \& Jacobs, George M. (2010). Essentials for Successful English Language Teaching. London: Continuum International Publishing Group

Krashen, Stephen D. (2009). Principles and Practice in Second Language Acquisition. Introduction to the Internet Edition.

Lai, Emily R. (2011). Motivation: A Literature Review. Research Report. Retrieved from: http://www.pearsonassessments.com/research

Peace Corps, Information Collection \& Exchange, Washington DC USA. TEFL/TESL: Teaching English as a Foreign or Second Language. The Manual prepared by the Center for Applied Linguistics, 1989, accessed through the website: http:/www.peacecorps.gov.

Ricahrds, J. C. \& Schmidt, Richard. (2002). Longmen Dictionary of Language Teaching \& Applied Linguistics, Third Edition, London: Pearson Education Limited

Richards, J. C. \& Lockhart, C. (2007). Reflective Teaching in Second Language Classrooms. USA: Cambridge University Press.

Terrell, Tracy D. (1977). A Natural Approach to Second Language Acquisition and Learning. The Modern Language Journal. Accessed in 2011 through http://www.jstor.org/stable/324551 
Ur, Penny. (2009). A Course in Language Teaching. Practice and Theory. UK: Cambridge University Press

Vansteenkiste, M., Lens, W. \& Deci, E. L. (2006). Intrinsic Versus Extrinsic Goal Contents in Self-Determination Theory: Another Look at the Quality of Academic Motivation. Educational Psychologist, 41 (1), 19-31. Lawrence Erlbaum Associates, Inc.

Westwood, Peter. (2008). What teachers need to know about Teaching Methods. Australia: Acer press 